\title{
IS CHINA'S BELT AND ROAD INITIATIVE (BRI) A CASE OF CROSS COUNTRY DYNAMIC SYNERGY?
}

\author{
Prof Dr M S S el Namaki \\ Dean, Victoria University, School of Management, Switzerland. \\ Dean (Retired) Maastricht School of Management, MSM, The Netherlands.
}

\begin{abstract}
China's Bridge and Road Initiative or BRI is emerging as the new bulwark of a newly reconfigured World economy. The initiative is presented as the conceptual and operational framework for the restructuring of the global economy. Foundations are designed to be all inclusive. There is capital, trade, technology and human resource elements. There are outward flow, inward flows, bilateral flows and regional flows. It draws a whip of economic exchange that run all the way from Spain through Germany, Turkey and Greece to Pakistan and ultimately China. It is projected as " a Chinese idea but for everyone's benefit". An effort that will "drive trade and prosperity through Chinese built infrastructure". And as President Xi puts it "....to .......encourage the building of systems of fair, reasonable and transparent global trade and investment rules.BRI will, to all appearances, require different conceptual foundations from those that guided Raegan's globalization efforts and the waves that followed. Those were largely based on competition and a country situational dominance based on a unique comparative advantage. BRI's political and economic context will advance a different foundation: cross country dynamic synergy. And this is the core of the following article.The article starts with a brief analysis of the conceptual framework of the globalization that emerged in the 80's and contrast that with the principles of cross country dynamic synergy that are adopted today. The article will go further to analysis the principles of the BRI and how those are based on dynamic synergy concepts as well as dynamic synergy application among the players. The article concludes with a projection of the longer term implications of BRI.

The article provides a novel application of cross country dynamic synergy concept to a present day event of unusual scope and potential.
\end{abstract}

KEYWORDS: China's Belt, Road Initiative (BRI), dynamic synergy

\section{The problem}

China's Bridge and Road Initiative or BRI is emerging as the new bulwark of a newly reconfigured World economy. The initiative is presented as the conceptual and operational framework for the restructuring of the global economy. Foundations are designed to be all inclusive. There is capital, trade, technology and human resource elements. There are outward flow, inward flows, bilateral flows and regional flows. It draws a whip of economic exchange that run all the way from Spain through Germany, Turkey and Greece to Pakistan and ultimately China. It is projected as " a Chinese idea but for everyone's benefit". An effort that will "drive trade and prosperity through Chinese built infrastructure". And as President $\mathrm{Xi}$ puts it "...to ......encourage the building of systems of fair, reasonable and transparent global trade and investment rules

BRI will, to all appearances, require different conceptual foundations from those that guided Raegan's globalization efforts and the waves that followed. Those were largely based on competition 
and a country situational dominance based on a unique comparative advantage. BRI's political and economic context will advance a different foundation: cross country dynamic synergy. And this is the core of the following article.

The article starts with a brief analysis of the conceptual framework of the globalization that emerged in the 80's and contrast that with the principles of cross country dynamic synergy that are adopted today. The article will go further to analysis the principles of the BRI and how those are based on dynamic synergy concepts as well as dynamic synergy application among the players. The article concludes with a projection of the longer term implications of BRI.

The article provides a novel application of cross country dynamic synergy concept to a present day event of unusual scope and potential.

\section{Comparative advantage vs dynamic synergy}

Comparative advantage as a base for cross country exchange is a concept advocated by $\mathrm{M}$ Porter in one of his early works. Country strategies according to Porter are tantamount to "building defenses against the competitive forces or finding positions in the industry where the forces are the weakest". Porter continues to assert that the "key to growth -even survival- is to stake out a position that is less vulnerable to attack from opponents whether established or new, and less vulnerable to erosion from the direction of buyers, suppliers and substitute goods". A position that delivers a competitive advantage allowing the organization to outperform its competition. Strategic thinking should, therefore, focus on building and sustaining competitive advantage (Porter, 1979, 1985, 1990).

Porter's concepts of competitive advantage at company and country levels, commanded considerable following but ran out of steam. Contextual relevance as much as conceptual flaws triggered their decay. They were developed during Reagan's free market gospel, an era overtaken by sobering events. And their conceptual premise that barriers would enhance and extend a competitive advantage, gradually lost ground. Capital market turbulence and disruptive technologies, among others, did away with barriers whether psychological or physical and innovative disruption, replaced barrier setting. Competitive advantage is, today, sudden in emergence and short in life span.(McGrath, 2013).

A substitute that seems to be taking hold is dynamic synergy (El Namoki, 2012, 2016). Synergy connotes interaction between two or more forces in a way that leads to a combined output that is greater than the sum of the individual components. Synergy could also be viewed as the creation of a whole that is greater than the simple sum of its parts. Synergy could deliver performance efficiencies, capital utilization opportunities or revenue enhancement initiatives.

And synergy could exist across countries.

Cross country synergy could be factor driven, efficiency driven, technology driven, or wealth driven. Factor driven countries operate within a natural resource and labor supply framework. Wellfunctioning goods markets, transformation markets, technology markets, labor markets and financial markets drive efficiency driven economies. Product, process and market innovations lead the way to an innovation driven economy. Wealth drives an economy when capital assets, capital product innovation and capital investment competencies deliver economic growth.

Synergy could be derived from today's performance or tomorrows flows or silent signals, or both. Today's performance synergy could relate to technology, tangible assets, strategic behavior and venture creation. It could also relate to functional areas of performance as manufacturing, investment or trade. 
But country synergy could also emerge out of what we may term silent signals or change in the task and universal environment of the country or countries in question (Ansoff, 1965). Disruptive technologies are typical for those silent signals. Those could emerge from nowhere and lead to a massive change in the relative positions of forces and players. And emerging synergies.

\section{Figure}

\section{The dynamic synergy concept}

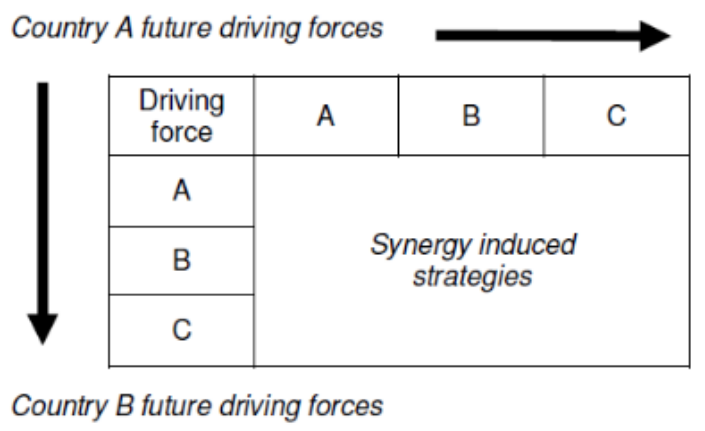

Source: El Namaki, 2016

\section{The BRI framework}

BRI framework is broad and ambitious. Statements featuring in the respective State Council stresses "embracing the trend towards a multi polar world, economic globalization, cultural diversity and greater IT application". It goes further to state that the initiative is designed to "uphold the global free trade regime and the open World economy in the spirit of open regional cooperation". And, in the process, it promotes connectivity of Asian, European and African continents, align development strategies, tap market potentials promote investment, enhance consumption, stimulate demand, induce job creation and encourage cultural exchange.

When it comes to the specific rational for China's initiation of this effort, the State Council stresses China's commitment to open up and build a pattern of involvement and global integration. Also to expand and deepen its opening up and shoulder more global responsibilities and obligations within its capabilities.

If one is probe further, one can discern three fundamental premises:

- China's search for new economic impetus. China's recent economic growth levels are lower than historical performance. Problems of excess manufacturing capacity, real estate market bubbles and State enterprises weaknesses have to find a structural solution. . BRI focus on infrastructure development thus creating effective venues for economic growth and a venue for greater economic globalization. 
- China's search for energy. Central Asian partners in BRI are endowed with energy and China's economic growth relies on that. BRI infrastructure projects as the new gas pipelines in Central Asia and new deep water harbors in South Asia are all a step in that direction.

- China's strategic and geopolitical interests. China wants to build a cordon sanitary of regional stability around itself. Chinese leadership firmly believes that economic prosperity is the only way to maintain peace in its fragile neighborhood. (World Economic Forum, Nov, 2015)

All in all the BRI provides a response to key structural questions of short and long term nature.

\section{The BRI dynamic synergy dimension}

As we said earlier, dynamic synergy is a function of the future driving forces of the constituents. China will undoubtedly experience a torrent of economic events triggered by projects conducted within the framework of the BRI itself, activities of the Asian Infrastructure Investment Bank, the impending internationalization of the RMB (Batten and Szilagyi, 2016),further globalization of the Chinese capital markets (Black and Morrison, 2010) and the impact of Chinese technology surge.

Outlook with regards to partners in central Asia and ASEAN, will bear the marks of those countries' market liberalization, proliferation of e technologies, enhanced capital markets, greater FDI inflows, expanded Infrastructure investment and extended tourism.

Europe's involvement will depend on the outcome of current shifts in economic and political currents within the EU. There seem to be an EU search for ways and means of coping with para dig shifts in political alliances, cross country economic partnerships, radical technology shifts and changing investment flows. The outcome is still to be seen but it could very well be conducive to a closer BRI economic and political cooperation.

Russia's situation will be influenced by developments within the Russian energy industry, the expansive role of minerals and metals industry, the proliferation of the defense industry, the restructuring of the Russian capital markets and the advent of new supply chains. (The Economist, Apr 15th 2015). A possible outcome could include an expansion of logistics and transportation infrastructure, closer capital market links and closer defense industry technology cooperation, among others.

All in all BRI will, more likely than not, create strong forces that may induce tangible economic and political currents and, in the process, re configure globalization as we knew it.

\section{BRI induced strategic behaviors}

Some specific strategic behaviors may emerge from BRI dynamics. Those could include:

- Restructuring of industries: A cross country industry synergy could induce a restructuring strategy of an industry leading to this industry's life cycle adjustment or even decline.

- Seeking concentration: A synergy could induce a strategy of merger and Acquisition and a state of increased concentration or market share dominance by key players.

- Aligning currencies: Synergy between respective country currencies could lead to a strategy of currency swap and possible liberalization of current account and capital account transactions. 
- Aligning capital markets: Synergies between respective two country capital markets could lead to a strategy of partial or total integration between key institutional players and a harmonization of policy guidelines.

- Seeking capital market innovation: Capital market synergies could lead to the emergence of products and instruments innovation strategies.

- Enhancing FDI flows: Investment-rooted synergies could lead to a strategy of enhancing FDI flows in order to acquire a. lasting interest or an effective control over a business entity or an industry operating within a synergy domain

\section{Summary and conclusions}

China's Bridge and Road Initiative or BRI is emerging as the new bulwark of a newly reconfigured World economy. The initiative is presented as the conceptual and operational framework for the restructuring of the global economy. Foundations are designed to be all inclusive. There is capital, trade, technology and human resource elements. There are outward flow, inward flows, bilateral flows and regional flows. It draws a whip of economic exchange that run all the way from Spain through Germany, Turkey and Greece to Pakistan and ultimately China. It is projected as " a Chinese idea but for everyone's benefit". An effort that will "drive trade and prosperity through Chinese built infrastructure". And as President Xi puts it "....to .......encourage the building of systems of fair, reasonable and transparent global trade and investment rules “

BRI is based on a different conceptual foundations from those that guided Raegan's globalization efforts and the waves that followed. Raegan's focus on economic supremacy based on unique country competitive advantage is replaced by cross country dynamic synergy, a concept based on conducive alliance and collective added value. And this is the focus of the article.

The article starts with a brief analysis of the conceptual framework of the globalization that emerged in the 80's and contrasts that with (the author's) cross country dynamic synergy concept, the apparent premise of the BRI effort. The article explores the foundations of the BRI, the strategic goals and objectives, the driving forces of prospective partners and the potential longer term outcome. The situation in Russia is given as an illustration. Specific strategic behaviors including industry restructuring and capital market alignment, may emerge as a result of BRI dynamics .

The article provides a novel application of cross country dynamic synergy concept to a present day event of unusual scope and potential.

\section{References}

1. Christensen, C. M.; Raynor, M. and McDonald, R. (2015), "What is disruptive Innovation?" Harvard Business Review, Vol. 93, No. 12, pp. 44-53.

2. Corporate Strategy", McGraw Hill, New York, 1965

3. El Namaki M, (2012), "Does the thinking of yesterday's management Gurus Imperil today's companies?" Ivey Business Journal, available from: http://iveybusinessjournal.com/publication/does-the-thinking-of-yesterdays-management-gur us-imperil-todays-companies. 
4. El Namaki M. (2016), "Dynamic synergy analysis in international business: Concept and application to two players China and Russia", Scholedge International Journal of Management \& Development, Vol. 3, No. 7, pp. 129-136.

5. Eurasian Union Brochure 2014 - English

6. Mackintosh, S. M. (2016), "The Creation of the Asian Infrastructure and Investment Bank: America's Loss and China's Gain", World Economics, Vol. 17, No. 3, pp. 25-38.

7. McGrath, R. G. (2013), The End of Competitive Advantage: How to keep your Strategy moving as fast as your business, USA: Harvard Business Review Press.

8. Porter, M. (1979), "How competitive forces shape strategy", Harvard Business Review, Vol. 57, No. 2, pp. 137-145.

9. Porter, M. (1985), Competitive Advantage, US: Free Press.

10. Porter, M. (1990), "The Competitive Advantage of Nations", Harvard Business Review, Vol. 68, No. 2, pp. 73-93.

11. Russia-China Investment Fund (2012), About Us, [Online] available from: www.rcif.com [accessed on 3 December 2016].

12. The Economist, (2015), "The Russian financial rally", The Economist, 15 A22015, [Online] available

from: http://www.economist.com/blogs/freeexchange/2015/04/russian-financial-Rally [accessed on 3 December 2016].

13. Why Europe can't afford to ignore China's New Silk Road, World Economic Forum, and 16 Nov, 2015).

14. Wilson, J. L. (2016), "The Eurasian Economic Union and China's Silk Road:Implications for the Russian-Chinese relationship", European Politics \& Society, Vol. 17, No. 1, pp. 113-132.

15. Zhou, X. (2016), "Yuan given to Russia under currency swap deal", SouthChina Morning Post, 2 Mar 2016 [Online] available from:Http://www.scmp.com/business/article/1919707/yuan-given-russia-under-currency-swa p-deal [accessed on 3 December 2016]. 